\title{
Integrated Approach to Determine Operational Integrity of Crane Metal Structure
}

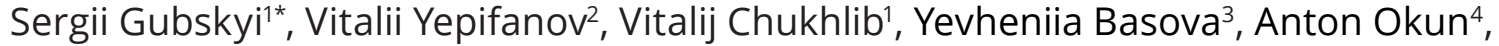 \\ Maryna Ivanova ${ }^{3}$, Olga Panamariova ${ }^{5}$
}

\footnotetext{
${ }^{1}$ Department of Plastic Metal Working, Institute of Education and Science in Mechanical Engineering and Transport, National Technical University "Kharkiv Polytechnic Institute", 2, Kyrpychova str., 61002, Kharkov, Ukraine

2 Department of Information Technologies and Systems of Wheeled and Tracked Vehicles named the A. A. Morozova, Institute of Education and Science in Mechanical Engineering and Transport, National Technical University "Kharkiv Polytechnic Institute", 2, Kyrpychova str., 61002, Kharkov, Ukraine

${ }^{3}$ Department of Mechanical Engineering Technology and Metal-Cutting Machine Tools, Institute of Education and Science in Mechanical Engineering and Transport, National Technical University "Kharkiv Polytechnic Institute", 2, Kyrpychova str., 61002, Kharkov, Ukraine

${ }^{4}$ Department of Lifting and Transporting Machines and Equipment, Institute of Education and Science in Mechanical Engineering and Transport, National Technical University "Kharkiv Polytechnic Institute", 2, Kyrpychova str., 61002, Kharkov, Ukraine

${ }^{5}$ Department of Hydraulic Machines, Institute of Education and Science in Mechanical Engineering and Transport,

National Technical University "Kharkiv Polytechnic Institute", 2, Kyrpychova str., 61002, Kharkov, Ukraine

* Corresponding author, e-mail: gubskiyso@gmail.com
}

Received: 23 March 2019, Accepted: 06 May 2019, Published online: 01 August 2019

\begin{abstract}
One of the elements limiting the crane life cycle and affecting the safety of its operation is a metal structure. Currently, there is no single scientifically-based approach to assess the operational integrity of crane metal structures. The paper deals with issues related to the development of an integrated approach to determine the operational integrity of crane metal structures, based on a combination of numerical methods of calculation (the finite element method and boundary states calculation) and magnetic coercive non-destructive control. The research of the influence of the metal chemical composition, its microstructure and the controlled elements thickness on coercive force values have been carried out. In order to take into account these parameters, it is suggested to use certificated experimental samples with variable cross sections. The practical value of the research is to apply the integrated approach that will eliminate the disadvantages of a separate method, complement these methods, increase the objectivity and accuracy of determining the operational integrity of crane metal structures.
\end{abstract}

\section{Keywords}

crane metal structure, coercive force, operational integrity, boundary states calculation, finite element method, crane life cycle

\section{Introduction}

Cranes are high danger objects. People's lives depend on the safety of their operation. Major factors limiting the productivity, reliability, life cycle of cranes and affecting the safety of its operation are metal structures and dynamic loads from vibrations [1-5]. The cost of crane metal structures is about $70 \%$ of the total crane cost. Consequently, preventing the occurrence of operational defects (cracks, plastic deformations etc.) in the crane metal structure is a vital scientific and practical task.

Particular attention should be paid to crane metal structures that have worked out their normative life cycle.
One of the steps to determine crane operational integrity and to extend their normative life cycle is to use destructive or (and) non-destructive control (NDC) methods. It is important to avoid the occurrence of operational defects, to detect them at the initial stage, which means the formation of a stress-strain state, that can lead to a defect (the so-called "Bifurcation point" [6]). This task can be solved with the use of NDC methods.

"Active" (magnetic coercive, ultrasonic etc.) and "passive" NDC methods (acoustic emission, magnetic metal memory, strain-measuring etc.) have been scientifically 
substantiated and have some disadvantages (for example, comparison of passive and active magnetic methods showed the advantage of active NDC methods [7]).

For instance, positive research results, as monitoring NDC methods, give the strain-measuring [8] and magnetic coercive methods [9].

Recent research allows us to use the magnetic coercive NDC method in the practice of diagnostics of the crane metal structure state based on the "risk factor" [10-11].

The scientific approach of using artificial intelligence systems for solving applied problems in the field of manufacturing engineering is stated in the paper [12], as well as the related methodology based on the implementation of artificial neural networks for manufacturing systems is proposed.

It is necessary for cranes, that have worked out their normative life cycle and operate in heavy mode, to carry out fatigue verification calculations according to loads that are repeatedly acting during the crane life cycle. As the practice shows fatigue calculations are the most difficult. For instance [13-14], deals with the issues of technical diagnostics and fatigue calculations of metal structures of crane tracks at a metallurgical plant. But the crane metal structure itself was not calculated.

An integrated approach to determine the operational integrity of crane metal structures based on a combination of numerical methods of calculation (the finite element method and boundary states calculation) and magnetic coercive non-destructive control has been proposed. The integrated approach will eliminate the disadvantages of a separate method, complement these methods, increase the objectivity and accuracy of determining the operational integrity of crane metal structures.

\section{Material and methods}

KRM-CK-2M structurescopes are used to carry out non-destructive control (Fig. 1).

As it is known

- the change of the rolled steel thickness causes the change of the metal microstructure grain size;

- chemical composition deviations of the steel are specified by regulations.

An investigation to determine the influence of the grain size and chemical composition deviations of the steel on coercive force values was carried out at the lifting and transporting equipment establishment. The rolled steel entering the production under the incoming inspection was not only subjected to the chemical analysis and mechanical

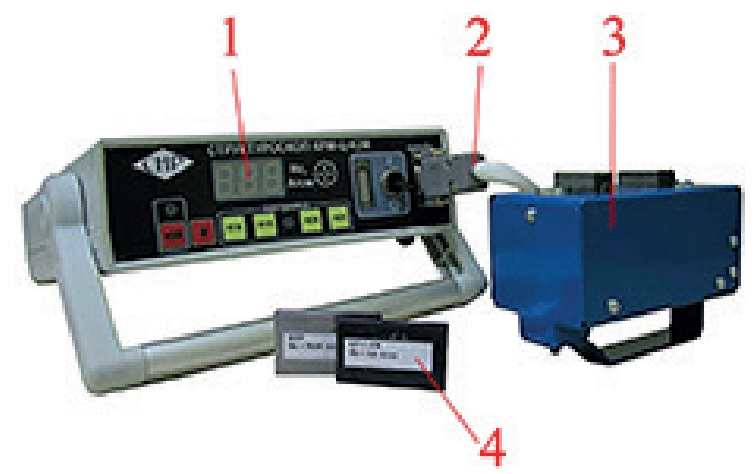

Fig. 1 The exterior of the KRM-CK-2M device: 1 - measuring block; 2 - connecting cable; 3 - transformer; 4 - control samples

testing, but also to the metallographic research with initial coercive force measurements. It was analyzed 132 metal samples and each sample had a certain thickness.

The following results were obtained (Fig. 2, Table 1).

It is shown in Fig. 2, two identical metal samples of low carbon steel with different grain sizes ( 6 and 10 points) havea difference in the coercive force values $\left(\Delta H_{\mathrm{C}}=0.36 \mathrm{~A} / \mathrm{cm}\right)$. Larger coercive force values have a sample with a smaller grain size.

Therefore, an increase in the grain size $(d)$ is accompanied by a decrease of the yield strength $\left(\sigma_{0.2}=1 / \sqrt{ } d\right.$, MPa), and the coercive force as well $\left(H_{C}=1 / d, \mathrm{~A} / \mathrm{cm}\right)$ [15].

It is seen from Table 1, the chemical composition has an impact on the coercive force up to $\Delta H_{C}=0.66 \mathrm{~A} / \mathrm{cm}$ for $09 \mathrm{G} 2 \mathrm{C}-12$ steel with the grain size of 9 points and the thickness of $6 \mathrm{~mm}$.

It could be also mentioned that when controlling rolled steel made of one metal, but with different thicknesses, a gradual lowering of the coercive force values was obtained with an increase in the metal thickness to a certain value (Fig. 3).

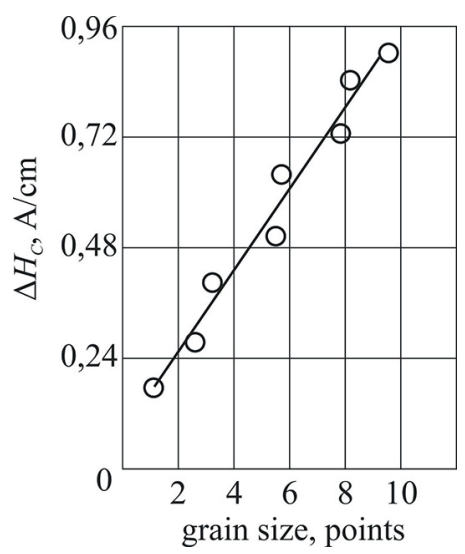

Fig. 2 The dependence of the coercive force additive $\left(\Delta H_{\mathrm{C}}, \mathrm{A} / \mathrm{cm}\right)$ with respect to the grain size for the low carbon steel 
Table 1 The results of the NDC method for the 09G2C-12 rolled steel samples with variable chemical composition (the grain size was 9 points according to GOST 5639-82, the thickness was $6 \mathrm{~mm}$ )

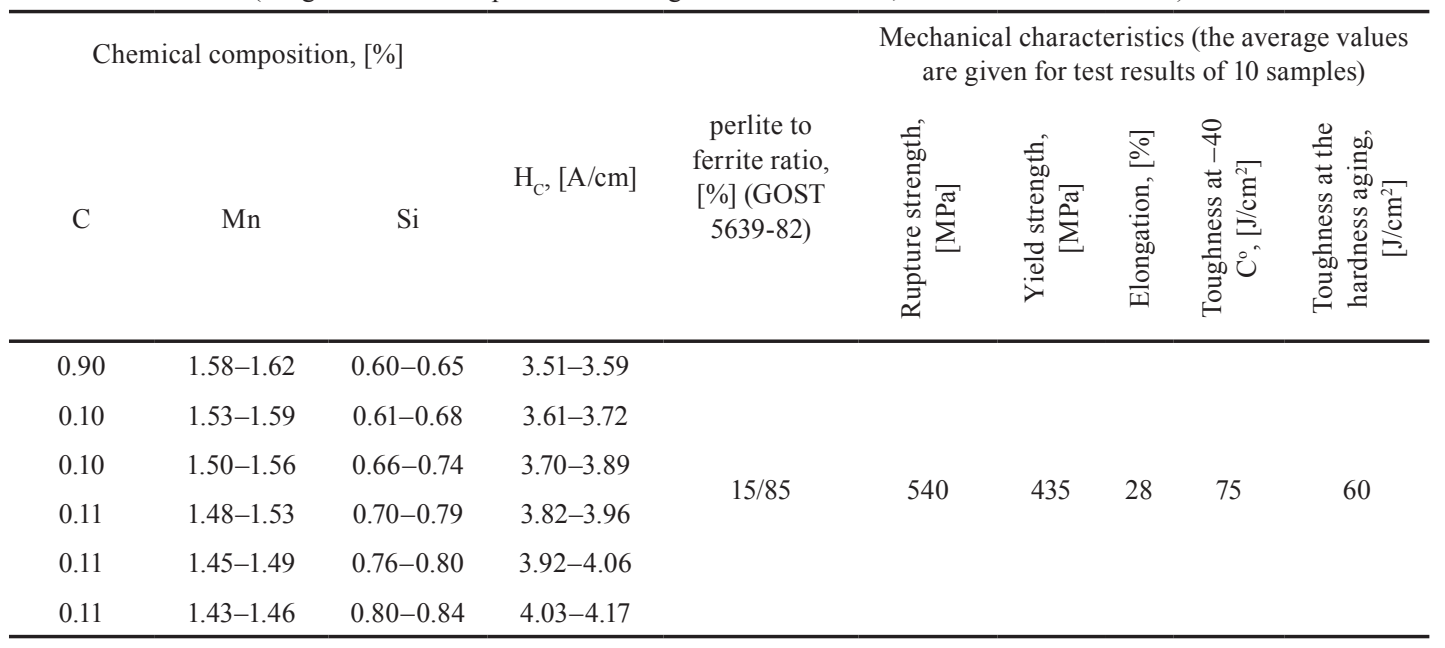

Consequently, the effects of the grain size, the deviations of chemical element weight fractions in steels, the thickness of controlled elements of metal structure on the coercive force values are significant. If do not take into account these effects, it could lead to a significant error in the results of the NDC method analysis of crane metal structures.

To solve this problem, a method with the use of the certificated experimental samples with variable cross sections, known quantities of mechanical characteristics, the chemical composition, microstructure and coercive force values in each section of the sample has been proposed (Fig. 4 and Fig. 5) [16].

To analyze the results obtained by the magnetic coercive NDC for crane metal structures with different thicknesses, it is required to recalculate all coercive force measurements to the thickness of $8 \mathrm{~mm}$. This thickness is chosen based on the KRM-CK-2M structurescope verification before operation

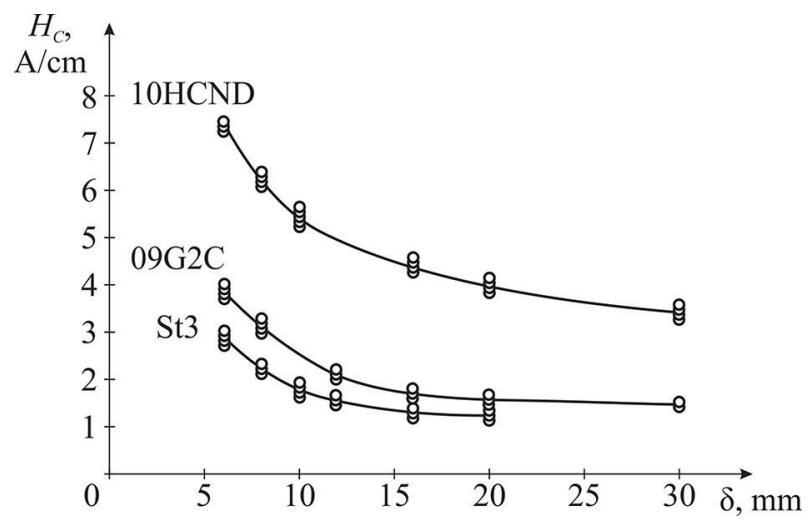

Fig. 3 The dependence of the coercive force values $\left(H_{\mathrm{C}}, \mathrm{A} / \mathrm{cm}\right)$ with respect to the rolled steel thickness $(\delta, \mathrm{mm})$ with the grain size was 9 points according to GOST 5639-82 that was carried out on the metal sample with the thickness of $8 \mathrm{~mm}$ (this sample is supplied with the structroscope). All experimental dependences shown in [10] were deduced for the metal thickness of 8-10 mm.

The technology of making samples with variable cross sections was developed. A passport of the magnetic control for the experimental samples with variable cross sections was devised according to the results of the chemical analysis, mechanical tests, metallographic studies and coercive force values. It has been manufactured 115 certificated experimental samples with variable cross sections.

In order to automate the processing and analysis of the magnetic coercive NDC results, Metal v2.2 computer program was developed and presented in [17]. More than 100 units of certified samples of various crane steels have been added into the program database. This allows selecting the desired sample from the already developed program database. The following functions are implemented in the program:

- taking into account the influence of the grain size, the deviations of chemical element weight fractions

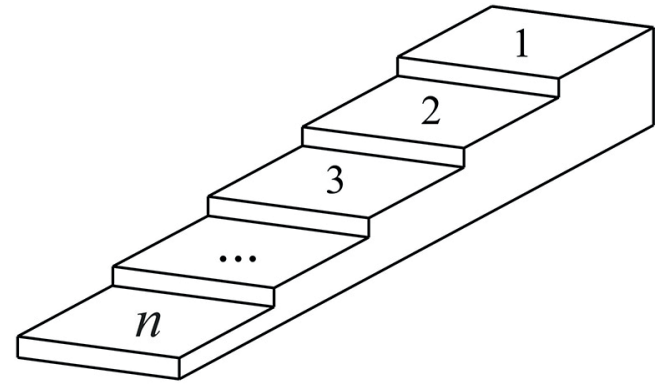

Fig. 4 The certificated experimental sample with variable cross sections, where $n$ is a number of steps 


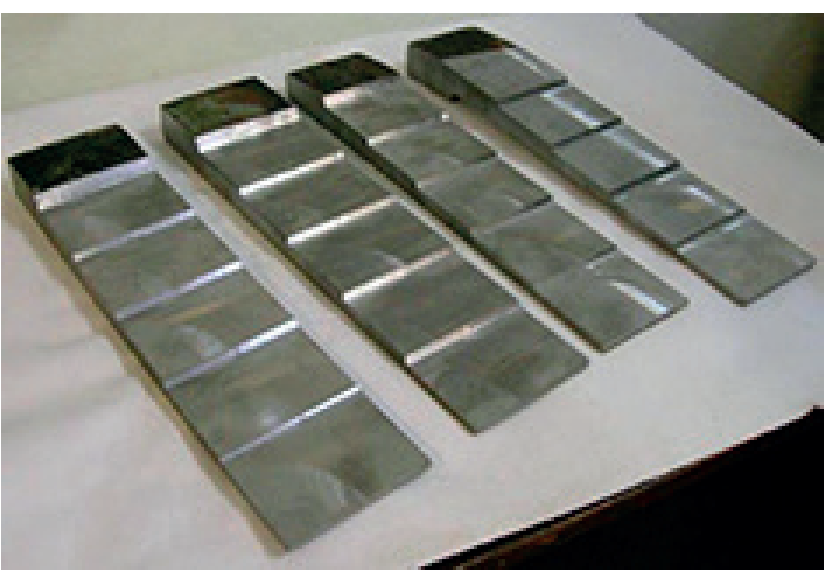

Fig. 5 The exterior of the certificated experimental samples with variable cross sections

in steels, the thickness of controlled elements of metal structure on the coercive force values;

- developing the curves that clearly represent a distribution of coercive force on the surface of controlled metal structures;

- calculating the life cycle of crane metal structures;

- printing and storaging the generated results in the form of reporting documentation (database) that can be used in further research.

\section{The verification fatigue calculation for a crane metal structure under operating loading}

It is necessary to choose a specific technological cycle (STC) for the verification fatigue calculation of the crane metal structure under operating loading [18-19] (one or more). Further, it is required to build a three-dimensional model of an overhead crane in a computer program (for example, SolidWorks, ANSYS, etc.), set boundary conditions, apply forces for each stage of STC loading, and carry out modeling by means of the finite element method (FEM) [20-21] and finally, indicate metal structure elements (calculation zones) with an increased stress level and a large stress range $\left(\Delta \sigma=\sigma_{\max }-\sigma_{\min }\right)$.

As a result of the simulation, it is obtained the stresses in the most loaded elements of the crane metal structure for various calculation cases. It is necessary to schematize changes of these stresses and carry out the reduction of asymmetric stress cycles to equivalent symmetric ones by using the rainflow-counting method [22]

$\sigma_{j}=\left\{\begin{array}{c}\sigma_{a j}+\Psi_{\sigma} \cdot \sigma_{m}, \sigma_{m}>0 \\ \sigma_{a j}<0\end{array}\right.$, where: $\sigma_{J}$ - the amplitude of a reduced symmetric stress cycle, $[\mathrm{MPa}] ; \sigma_{a j}-$ the amplitude of an asymmetric stress cycle, $[\mathrm{MPa}] ; \sigma_{m}$ - the average value of a stress cycle, $[\mathrm{MPa}] ; \psi_{\sigma}-$ the coefficient of the steel sensitivity to the cycle asymmetry.

The obtained amplitudes of reduced symmetric stress cycles for all calculated zones must satisfy the following condition

$\sigma_{j}=<\sigma_{-1 K}$,

where $\sigma_{-1 K}$ - the fatigue limit of the calculation zone, calculated on the basis of the basic fatigue limit considering the influence of the calculated metal structure element thickness, [MPa] [18].

If there are stresses that do not lead to the accumulation of damages in all calculated zones at the given STC, then the metal structure of the tested crane during the operating loading has an unlimited life cycle. If the condition (Eq. (2)) is not fulfilled, then it is necessary to make calculations for an ultimate life cycle for this calculated zone [18].

\section{Practical application}

It was considered an expert inspection of the overhead crane with the load capacity of 16 tons, the span length of 22.5 meters, the class of use under the U5 passport was ISO 4301/1, the year of production was 1989, the material was 09G2C-12 steel.

A magnetic coercive NDC method applying the certificated experimental samples with variable cross sections was used to estimate the real stress-strain state (SSS) of the crane metal structure.

As a result of magnetic coercive NDC of the crane metal structure, the biggest coercive force values were obtained in bearing box zones as well as in connection zones of the end and main beams. Metal in these zones were in a critical operating mode in the plastic deformation zone (Fig. 6) (MI 0.00-7.01-05, 2005).

The results of magnetic coercive NDC confirm the recorded defect-cracks in the bearing box zone (Fig. 7a) and in the connection zone of the end and main beams (Fig. 7b).

The complicated SSS of metal structures of the crane is connected with the unsatisfactory operation of its movement mechanism, including incorrect setting of running wheels of the crane. This fact is proven by Fig. 8 .

Further, a verification fatigue calculation of the metal structure of the crane under operating loading was carried out taking into account the unsatisfactory operation of the crane movement mechanism. 


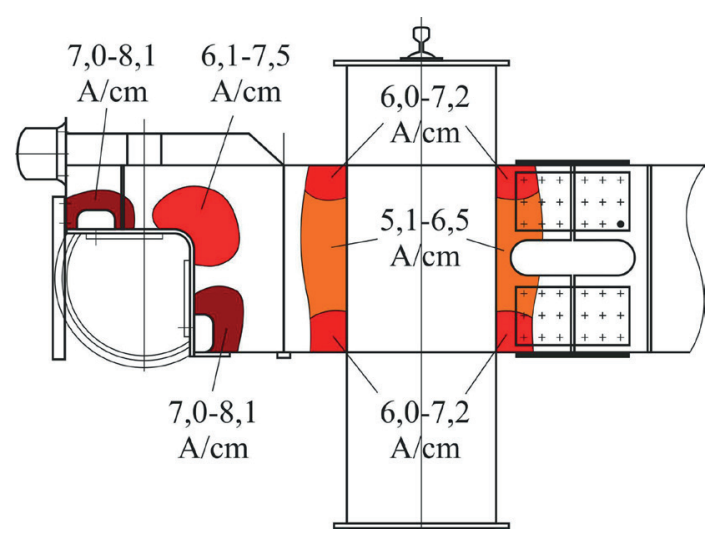

Fig. 6 The generalized results of the magnetic coercive NDC of the end beam of the overhead crane with the load capacity of 16 tons, the span length of 22.5 meters, the heavy mode of operation, the material was 09G2C-12 steel

The selected STC of the crane (the end beams and connection zones of the main and end beams of the crane were calculated) consisted of the lifting of a load in the extreme position from the end beam side, the crane movement, the trolley movement to another extreme position and load lowering. In total, this STC was divided into nine calculation cases.

a)

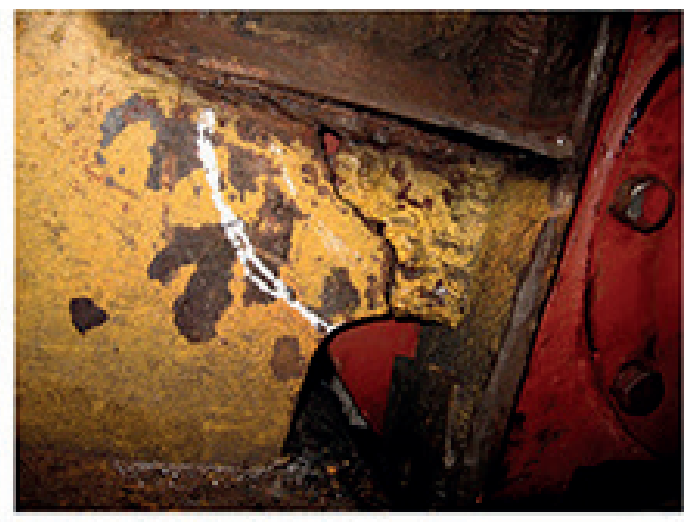

b)

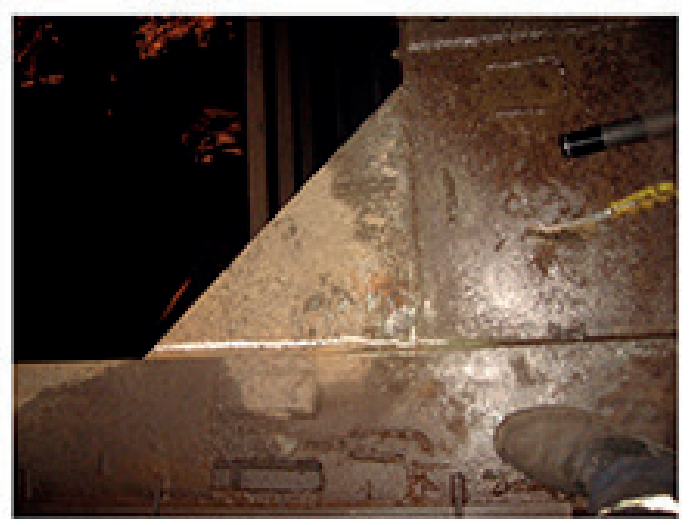

Fig. 7 Defect cracks (indicated by white color) in the bearing box zone (a) and the connection zone of the end and main beams (b) of the crane
Three-dimensional models of the overhead crane at a scale of 1:1 were built (Fig. 9). Shell-type elements were used for simulation. The model was simplified in comparison with the real object: mechanisms, galleries, mechanisms for mounting brackets and other auxiliary elements of metal structures were not considered.

In the case of the STC, the following components were taken into account: the own weight of the metal structure, the weight of the trolley, the weight of the cargo; the speed of the load lifting and crane movement; the acceleration when crane is moving and under free fall; dynamic coefficients that arise when the "separation" from the base and the completion of the load lifting; the shock factor for the crane and the trolley, which take into account the vertical load that arises when the crane (trolley) movement due to roughness of the crane (trolley) track; inertial (horizontal) loads that arise when the crane movement (including from the deviation of cargo ropes during acceleration (braking) of the crane (trolley)); skewing loads that arise from unsatisfactory operation of the crane movement mechanism [19].

As a result of the simulation of nine computational cases by the FEM, the subsequent schematization of the received stress changes and the reduction of asymmetric stress cycles to the equivalent symmetric ones, amplitudes of the stresses of the reduced symmetric cycles were obtained for all calculated zones. In CZ 1, CZ 3, CZ 5 the condition Eq. (2) was not fulfilled. It means that there are stresses in the calculation zones at this STC that lead to the accumulation of damages and the metal structure of the tested crane during the operating loading has a limited life cycle [18].

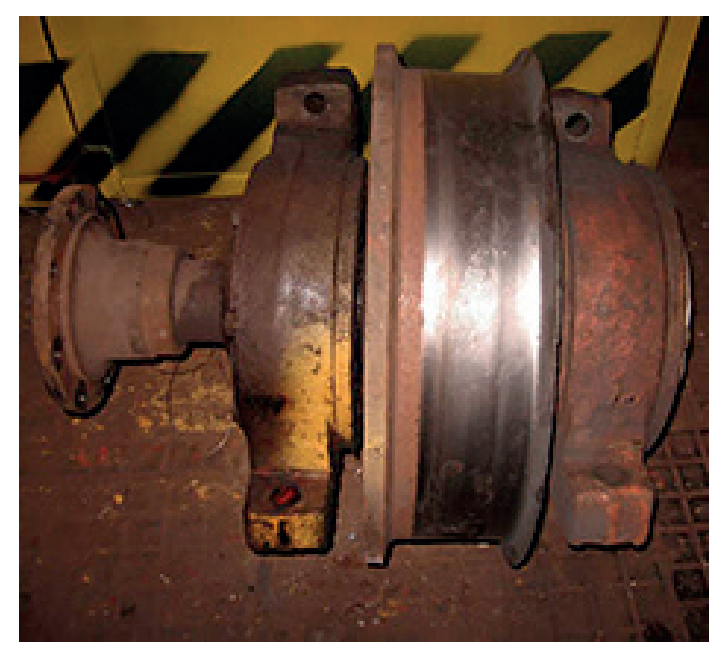

Fig. 8 An inappropriate wear and tear of the running wheel flange of the crane 

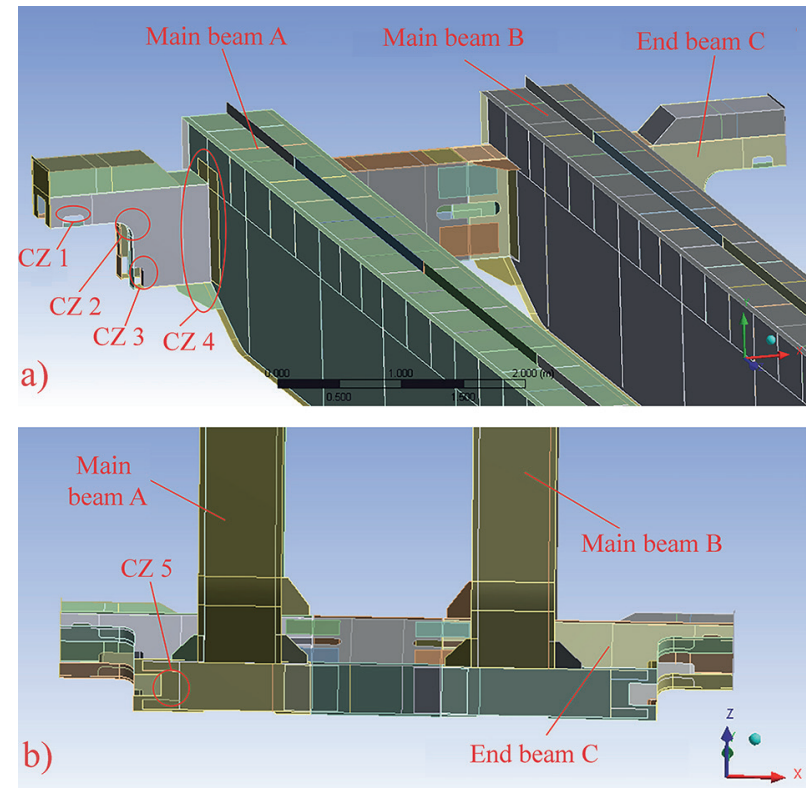

Fig. 9 A three-dimensional model of the overhead crane at 1:1 scale (CZ 1 ... CZ 5 - calculation zones)

\section{Conclusions}

Consequently, in this article:

- an integrated approach to determine operational integrity of crane metal structures based on a combination of numerical calculation methods (the finite element

\section{References}

[1] Wu, F. Q., Zhang, J., Yao, W. Q. "Fatigue life analysis of metallurgical bridge crane structure", Applied Mechanics and Materials, 437, pp. 181-185, 2013.

https://doi.org/10.4028/www.scientific.net/AMM.437.181

[2] Qi, K., Wang, W., Wang, X., Jiang, A, Liu, B., Guo, Z., Liu, J. "Safety assessment and fatigue life analysis of aged crane structures", In: 13th International Conference on Fracture, Beijing, China, 2013, pp. 1-5. [online] Available at: https://www.gruppofrattura.it/ocs/index.php/ICF/icf13/paper/download/11531/10910 [Accessed: 07 July 2018]

[3] Hryhorov, O. V., Gubskiy, S. O., Turchyn, O. V., Vyshnevetsky, G. V. "Teoretichne i eksperimental'ne doslidzhennya procesu peresuvannya mostovogo krana z perekosom. Zbirnik naukovih prac'yu" (Theoretical and experimental study of process of a bridge crane movement), Engineering, 19, pp. 7-17, 2017. [online] Available at: http://repo.uipa.edu.ua/jspui/handle/123456789/5576 [Accessed: 12 December 2018] (in Ukrainian)

[4] Loveikin, V. S., Romasevich, Y. A., Khoroshun, A. S., Shevchuk, A. G. "Time-Optimal Control of a Simple Pendulum with a Movable Pivot. Part 1", International Applied Mechanics, 54(3), pp. 358-365, 2018.

https://doi.org/10.1007/s10778-018-0887-x method and boundary states calculation) and magnetic coercive non-destructive control is proposed;

- to increase the reliability of the magnetic coercive non-destructive control, it is proposed to apply a method using the certificated experimental samples with a variable cross sections, known quantities of mechanical characteristics, the chemical composition, microstructure and coercive force values in each section of the sample;

- an example of the application of the integrated approach to determine the operational integrity of the overhead crane metal structure with the load capacity of 16 tons, the span length of 22.5 meters, manufactured in 1989 is shown. The results of monitoring and calculations showed the accumulation of fatigue damage in bearing box zones as well as in connection zones of the end and main beams of the crane (it is proven by Fig. 7 and 8).

For the further development of the proposed integrated method, it is necessary to implement the possibility of taking into account the stress-strain state of crane metal structures, which is defined by the magnetic coercive non-destructive control, in the fatigue calculations by introducing specific substantiated coefficients into the calculation scheme of the crane.

[5] Okun, A., Los, Y. "The controllability function method", U. P. B. Scientific Bulletin, Series D, 78(3), pp. 3-8, 2016. [online] Available at: https://www.scientificbulletin.upb.ro/rev_docs_ arhiva/rezb61_197751.pdf [Accessed: 07 July 2018]

[6] Baurova, N. I., Zorin, V. A. "Sposob diagnostirovaniya sostoyaniya konstrukcii" (The way to diagnose the state of the structure using liquid crystal polymers), Russian Federation, Patent RU 2395786, 2010. [online] Available at: http://www.findpatent.ru/patent/239/2395786.html [Accessed: 12 October 2018] (in Russian)

[7] Dybała, J., Nadulicz, K. M. "Diagnostics of welded joints using passive and active magnetic methods", Diagnostyka, 18(4), pp 51-59, 2017. [online] Available at: http://www.diagnostyka. net.pl/Diagnostics-of-welded-joints-using-passive-and-activemagnetic-methods, 79765,0,2.html [Accessed: 12 September 2018]

[8] Mantič, M., Kul'ka, J., Faltinová, E., Kopas, M. "Autonomous online system for evaluating steel structure durability", Diagnostyka, 17(3), pp. 15-20, 2016. [online] Available at: http://www.diagnostyka.net.pl/Autonomous-online-system-for-evaluating-steelstructure-durability,63668,0,2.html [Accessed: 05 October 2018] 
[9] Hryhorov, O. V., Petrenko, N. O., Gubskiy, S. O. "Magnitnokoercitivnij kontrol' kraniv z tovshchinami elementiv metalokonstrukcij ponad $40 \mathrm{~mm}$ " (Magnetic and coercive control of cranes with thicknesses of metal structures more than $40 \mathrm{~mm}$ ), Hebezeuge und Fördermittel, 1(49), pp. 4-11, 2016. [online] Available at: http:// repository.kpi.kharkov.ua/handle/KhPI-Press/25302 [Accessed: 12 October 2018] (in Ukrainian)

[10] "Metodichni vkazivki z provedennya magnitnogo kontrolyu napruzheno-deformovanogo stanu metalokonstrukcij pidjomnih sporud ta viznachennya ïh zalishkovogo resursu" (Methodical instructions on the magnetic control of the stress-strain state of metal structures of lifting structures and determination of their residual resource), LLC "Special Scientific Engineering", Kharkiv, 2005. (in Ukrainian)

[11] Kotelnikov, V. S. "Metody diagnostirovaniya i risk-analiza metallokonstrukcij gruzopod"emnyh mashin $\mathrm{v}$ upravlenii ih bezopasnost'yu" (Methods of diagnostics and risk analysis of lifting machinery metal structures in their safety management), Doctor of Sciences, Novocherkassk, 2006. [online] Available at: http:// tekhnosfera.com/view/284329/d [Accessed: 10 September 2018] (in Russian)

[12] Pavlenko, I., Trojanowska, J., Ivanov, V., Liaposhchenko, O. "Scientific and Methodological Approach for the Identification of Mathematical Models of Mechanical Systems by Using Artificial Neural Networks", In: Machado J., Soares F., Veiga G. (eds.) International Conference on Innovation, Engineering and Entrepreneurship. HELIX 2018., 1st ed., Lecture Notes in Electrical Engineering, Springer, Cham, Switzerland, 505, pp. 299-306, 2019.

https://doi.org/10.1007/978-3-319-91334-6_41

[13] Kul'ka, J., Faltinová, E., Kopas, M., Mantič, M. "Diagnostics and optimization of crane track durability in metallurgical plant", Diagnostyka, 17(3), pp. 41-46, 2016. [online] Available at: http:// www.diagnostyka.net.pl/Diagnostics-and-optimisation-ofcrane-track-durability-in-metallurgical-plant, 63949,0,2.html [Accessed: 15 September 2018]

[14] Kulka, J., Mantic, M., Faltinova, E., Molnar, V., Fedorko, G. "Failure analysis of the foundry crane to increase its working parameters", Engineering Failure Analysis, 88, pp. 25-34, 2018. https://doi.org/10.1016/j.engfailanal.2018.02.020
[15] Mikheev, M. N., Gorkunov, E. S. "Magnitnye metody stukturnogo analiza i nerazrushayushchego kontrolya" (Magnetic methods of structural analysis and non-destructive testing), 1st ed., Nauka, Moscow, Russia, 1993.

[16] Hryhorov, O. V., Okun, A. O., Gubskiy, S. O., Popov, V. A., Horlo, M. F. "Eksperimental'nij zrazok dlya kalibruvannya strukturoskopa" (Experimental sample for calibrating the structuroscope), Ukraine, Patent number 77319, 2013.

[17] Gubskiy, S. O., Okun, A. O. "Metal v2.2 Avtomatizaciya obrobki ta analizu rezul'tativ magnitno-koercitivnogo kontrolyu", (Metal v2.2 "Automation of processing and analysis of the results of magnetic coercive control"), Ukraine, Patent number 47890, 2013.

[18] Sokolov S. A. "Metallicheskie konstrukcii pod"emno-transportnyh mashin" (Metal constructions of lifting and transporting machines), 1st ed., Publishing house, Mechanical Engineering, St. Petersburg, Russia, 2005. (in Russian)

[19] Government. EUROPEAN STANDARD 2005 / EN 1993-1-3/ CEN / Eurocode 3: Design of steel structures - Part 1-9: Fatigue. FEDERATION EUROPEENNE DE LA MANUTENTION. Booklet 2 1998/ F.E.M. 1.001 3rd edition revised 1998.10.0./ HEAVY LIFTING APPLIANCES/ Rules for the design of hoisting appliances. Classification and loading on structures and mechanisms.

[20] Basova, Y., Nutsubidze, K., Ivanova, M., Slipchenko, S., Kotliar, A. "Design and numerical simulation of the new design of the gripper for manipulating of the rotational parts", Diagnostyka, 19(4), pp. 11-18, 2018. https://doi.org/10.29354/diag/94030

[21] Kotliar, A., Gasanov, M., Basova, Y., Panamariova, O., Gubskyi, S. "Ensuring the reliability and performance criterias of crankshafts", Diagnostyka, 20(1), pp. 23-32, 2019. https://doi.org/10.29354/diag/99605

[22] "Raschety i ispytaniya na prochnost'. Metody skhematizacii sluchajnyh processov nagruzheniya ehlementov mashin i konstrukcij i statisticheskogo predstavleniya rezul'tatov" (Strength calculation and testing. Representation of random loading of machine elements and structures and statistical evaluation of results), Standartform, Moscow, 2005. (in Russian) 